\title{
Nutraceuticals: A Review
}

Skylar A. Souyoul $\cdot$ Katharine P. Saussy $\cdot$ Mary P. Lupo

Received: October 16, 2017 / Published online: February 6, 2018

(C) The Author(s) 2018. This article is an open access publication

\section{ABSTRACT}

Skin aging is continuously influenced by various internal and external factors such as the biologic progression of cells, ultraviolet (UV) radiation, tobacco, nutritional deficiencies, and hormonal imbalances that lead to the degradation of skin cells. Through the degradation of skin cells, free radicals and inflammation weaken repair mechanisms and result in collagen and elastic fiber breakdown. The appearance of aging skin is highlighted by skin roughness, wrinkling, pigmentation change, telangiectasias, loss of elasticity, and decreased firmness, all of which are accelerated by these internal and external factors. Throughout the years, nutraceuticals have been studied to delay and fight against these internal and external factors, many of which are found in foods and byproducts consumed naturally. The aim of this review is to aid dermatologists in understanding the mechanism of action of popular

Enhanced content To view enhanced content for this article go to http://www.medengine.com/Redeem/ 276299605B0947D5.

S. A. Souyoul $(\bowtie) \cdot$ M. P. Lupo

Lupo Center for Aesthetic and General

Dermatology, New Orleans, LA, USA

e-mail: drsouyoul@drmarylupo.com

K. P. Saussy

Department of Internal Medicine, Tulane

University, New Orleans, LA, USA nutraceuticals and their possible efficacy in antiaging and skin health.

Keywords: $\beta$-Carotene; Fatty acids; Lutein; Lycopene; Minerals; Nutraceuticals; Polyphenols; Vitamin C; Vitamin E; Zeaxanthin

\section{INTRODUCTION}

The skin is the largest organ of the human body and is perpetually aging by both internal and external factors [1]. The internal factors are a part of the natural aging process within cells, but can be accelerated by external factors such as ultraviolet (UV) radiation, tobacco, inadequate nutrition, and hormonal imbalances. These external factors cause the production of free radicals and inflammation that fragment and degrade collagen and elastic fibers [2]. Over time, both these internal and external influences lead to increased skin roughness, wrinkling, pigmentation change, telangiectasias, loss of elasticity, and decreased firmness, giving skin its aged appearance [2,3].

Nutraceuticals are oral dietary components naturally found in foods and believed to have a medical or health benefit [4]. Dr. Stephen Defelice, who combined the words "nutrition" and "pharmaceutical," coined the term in 1989. Here, the theoretical action and clinical benefit of some dermatologic nutraceuticals are 
reviewed. The aim of this review is to aid dermatologists in understanding the mechanism of action of popular nutraceuticals and their possible efficacy in antiaging and skin health. This article is based on previously conducted studies and does not involve any new studies of human or animal subjects performed by any of the authors.

\section{AMINO ACIDS}

\section{$\mathrm{N}$-Acetylcysteine}

$\mathrm{N}$-Acetylcysteine is the prodrug form of L-cysteine and has both oral and topical bioavailability $[5,6]$. N-Acetylcysteine gives rise to glutathione, which is the most abundant endogenous intracellular antioxidant and plays a pivotal role in the body's antioxidant defense $[6,7]$. The rate of glutathione synthesis decreases as humans' age, leading to glutathione deficiency, which leaves the body susceptible to oxidative stress [7]. Increased oxidative stress leads to increased DNA damage and aging [7].

A study by Sekhar et al. [7] found that elderly subjects had significantly lower intracellular glutathione synthesis and concentrations when compared to younger subjects. After 2 weeks of cysteine and glycine supplementation, elderly subjects had a significant increase in their red blood cell glycine, cysteine, and glutathione concentrations [7]. In addition, after supplementation, there was a decline in both oxidative stress and plasma markers for oxidant damage [7]. The Food and Nutrition Board of the Institute of Medicine's recommended dietary allowance (RDA) of $\mathrm{N}$-acetylcysteine has not been established. Further clinical studies are needed to determine ideal daily consumption of $\mathrm{N}$-acetylcysteine to achieve maximal skin benefit.

\section{CAROTENOIDS}

Carotenoids are a family of over 600 fat-soluble plant pigments, approximately 20 of which are present in human tissues and blood [3, 8]. They are potent reactive oxygen species (ROS) scavengers, protecting the skin from oxidative stress [8]. Humans and animals cannot synthesize carotenoids, so they must obtain them via ingestion of foods or supplements [8]. Skin concentrations of carotenoids increase with ingestion of the components, but decrease with oxidative stress and UV exposure [3]. Here, we focus on four of the major dietary carotenoids: $\beta$-carotene, lycopene, lutein, and zeaxanthin.

\section{$\beta$-Carotene}

$\beta$-Carotene is a precursor to vitamin A. It protects cells from damage by inhibiting free radical and singlet oxygen-induced lipid peroxidation [3]. It also has photoprotective properties, which increase the minimal erythema dose (MED), and protects against sunburn development and photosuppression of the immune system $[3,8,9]$. In mice, $\beta$-carotene has been shown to prevent wrinkle formation and decrease matrix metalloproteinase (MMP)-9 activity, protecting the extracellular matrix (ECM) from degradation [3].

Foods rich in $\beta$-carotene are green leafy vegetables, orange root vegetables, and yellow or orange fruits [3]. $\beta$-Carotene is a precursor to vitamin $\mathrm{A}$; thus, the RDA is determined through consumption of vitamin A. The Food and Nutrition Board of the Institute of Medicine's RDA of vitamin A is $900 \mu \mathrm{g}$ retinol activity equivalency (RAE) a day for men and $700 \mu \mathrm{g}$ RAE a day for women ages 19 years and older [10]. According to the Institute of Medicine's Interconversion of Vitamin A and Carotenoid Units Table, $2 \mu \mathrm{g}$ of supplemental all-trans- $\beta$ carotene is equal to $1 \mathrm{RAE}$ and $12 \mu \mathrm{g}$ of dietary all-trans- $\beta$-carotene is equal to $1 \mathrm{RAE}$. Thus, the RDA of supplemental all-trans- $\beta$-carotene is $1800 \mu \mathrm{g}$ a day for men and $1400 \mu \mathrm{g}$ a day for women, and the RDA for dietary all-trans- $\beta$ carotene is $10,800 \mu \mathrm{g}$ a day for men and $8400 \mu \mathrm{g}$ a day for women [10]. Long-term $\beta$-carotene supplementation has been associated with an increased risk of lung cancer, so further studies are needed to determine the optimal daily allowance while accessing for supplementation health risks [9]. 


\section{Lutein and Zeaxanthin}

Lutein and zeaxanthin are the two primary xanthophyll carotenoids in the retina and are generally thought to promote eye health; however, significant amounts of both are found in human skin [11]. In both the skin and eyes, these carotenoids work as a filler to block damaging blue wavelengths and as antioxidants to prevent free radical damage $[11,12]$.

Juturu et al. [12] evaluated a daily oral supplement containing $10 \mathrm{mg}$ of lutein and $2 \mathrm{mg}$ of zeaxanthin isomers. They concluded that within 12 weeks, the supplement increased the mean MED and significantly improved skin tone, luminance, and color [12]. Other studies have shown that lutein and zeaxanthin protect keratinocytes from UV radiation-induced photoaging, stop ECM degradation by inhibiting MMPs, and decrease lipid peroxidation in the skin $[11,13]$. These skin effects can be seen with lutein and zeaxanthin oral supplementation, topical application, or both simultaneously for enhanced benefit $[11,13]$.

Humans are unable to produce lutein or zeaxanthin, so they must be obtained exogenously [10]. Both are found in highest concentration in green leafy vegetables, but are found in a more bioavailable form in eggs [13]. The Food and Nutrition Board of the Institute of Medicine's RDA of lutein and zeaxanthin has not been established; however, between 6-10 $\mathrm{mg}$ a day of lutein and $2 \mathrm{mg}$ a day of zeaxanthin has been recommended in previous studies [10, 12, 14]. Of note, the American Optometric Association recommends taking $10 \mathrm{mg}$ a day of lutein and $2 \mathrm{mg}$ a day of zeaxanthin if one is not getting adequate amounts through diet alone to potentially reduce the risk of age-related macular degeneration and cataracts [15].

\section{Lycopene}

Lycopene has no vitamin A activity, but is considered the best singlet oxygen quencher in the carotenoid family [3]. Studies have shown that consumption of tomato paste, which is high in lycopene, significantly lowers UV- induced erythema and decreases MMP-1 activity, an enzyme involved in the breakdown of collagen [16]. In vitro studies of lycopene have shown its ability to inhibit proliferation of several types of cancer cells via cell-cycle arrest and induction of apoptosis [3]. There is also a significant correlation between higher skin concentrations of lycopene and a decrease in skin roughness [3].

Foods rich in lycopene are tomatoes, pink grapefruit, and watermelon [10]. The Food and Nutrition Board of the Institute of Medicine has not established an RDA for lycopene, so further studies are needed to determine the optimal daily allowance while accessing for supplementation health risks.

\section{FATTY ACIDS}

\section{$\alpha$-Linolenic Acid, Eicosapentaenoic Acid, and Docosahexaenoic Acid}

Essential fatty acids make up long-chain polyunsaturated fatty acids that can be divided into two groups, omega-3 and omega-6 [17]. Omega-3 fatty acids originate from linolenic acid, whereas omega- 6 fatty acids originate from linoleic acid (LA) [17]. The three most common omega-3 essential fatty acids are alpha-linolenic acid (ALA), eicosapentaenoic acid (EPA), and docosahexaenoic acid (DHA) [17]. These three fatty acids lie on a metabolic spectrum with ALA serving as the precursor and EPA and DHA serving as ALA's metabolized products [18].

In the stratum corneum a combination of lipids serves as a protective barrier to the skin surface and cellular structure [19]. LA has the highest fatty acid concentration within the epidermis and serves as an important structural component [20], while omega-3 polyunsaturated fatty acids play an important anti-inflammatory role $[20,21]$. Polyunsaturated fatty acids such ALA, EPA, and DHA hinder the formation of pro-inflammatory cytokines such as prostaglandins, leukotrienes, tumor necrosis factor- $\alpha$, interferon- $\gamma$, and interleukins- 12 and $-6[20,21]$. Studies have reported a significant reduction in UV-radiation-induced 
inflammation when taking fatty acid supplements, attributed to the potential decrease in prostaglandin- $\mathrm{E}_{2}$ levels during the inflammatory response [17-19]. Another study reported an increase in the MED in study participants who took $4 \mathrm{~g}$ of EPA daily [20].

In 2017, Wang et al. demonstrated a way to quantify the skin's fatty acid concentration and composition using gas chromatography. The study resulted in a statistically significant increase in the concentration of EPA and DHA in the skin of mice within 2 weeks of initiating a diet supplemented with fish oil [18]. Four weeks after of initiating the supplemented diet, this increase plateaued [18].

Essential fatty acids must be consumed through diet or supplementation since humans do not have the enzymes to produce them de novo, leading to a variation in the fatty acid make up within the skin $[18,20]$. Omega-3 fatty acids, as well as omega- 6 fatty acids, are found primarily in oils such as flaxseed oil, canola oil, hemp seed oil, and other foods including coldwater fish, such as salmon and trout, nuts, and seeds $[17,20]$. The Food and Nutrition Board of the Institute of Medicine does not have an RDA for any of the fatty acids mentioned above because of a lack of evidence, but does have an adequate intake (AI), which is determined by the largest median intake where deficiency is extremely rare [22]. The AI for LA is $17 \mathrm{~g}$ per day for men and $12 \mathrm{~g}$ per day for women ages 19-50, and 14 and $11 \mathrm{~g}$ per day for men and women age 51 and above [22]. The AI for ALA is $1.6 \mathrm{~g}$ per day for men and $1.1 \mathrm{~g}$ per day for women ages 19 and older [22]. Additional studies are needed to determine the ideal daily dose of essential fatty acids to achieve maximal skin benefit.

\section{MINERALS}

\section{Copper}

Copper is a trace mineral found naturally in soil with many innate properties. Copper serves as an important cofactor in enzymatic reactions during collagen crosslinking with lysyl oxidase and skin pigmentation with tyrosinase $[23,24]$.
Copper promotes keratinocyte and fibroblast proliferation leading to skin rejuvenation and wound repair through its collagen crosslinking properties [25]. Lastly, copper has been used in topical treatments for wound healing to promote repair of damaged skin because of its antiinflammatory and anti-bacterial effects [25].

Dietary copper is found in highest concentration in nuts, seeds, seafood, meat, and grains [10]. Human deficiencies are rare and are most commonly seen in people with intestinal malabsorption [10]. The Food and Nutrition Board of the Institute of Medicine's recommended dietary allowance of copper is $900 \mu \mathrm{g}$ a day for men and women ages 19 and older [10]. Additional studies are needed to determine the ideal daily dose of copper to achieve maximal skin benefit.

\section{Selenium}

Selenium is a trace element, also referred to as an essential mineral, found in soil, water, and specific foods. It exists in multiple forms, but predominantly found in humans as selenomethionine [26]. It plays an important role in DNA synthesis and repair, cell apoptosis, and guarding against oxidative damage [26]. Selenium works through glutathione peroxidases and thioredoxin reductases, which remove damaging lipid hydroperoxides, hydrogen peroxide, and peroxynitrite formed during oxidative stress, leading to cell membrane stabilization and defense against DNA damage [27, 28].

Selenium, in multiple forms, is found in highest concentration in animal proteins such as meat and seafood, the majority of which are highly bioavailable [29]. The precise concentration of selenium is dependent on the selenium concentration within the soil where those animals and plants were produced, which varies between land sources [29]. The Food and Nutrition Board of the Institute of Medicine's $\mathrm{RDA}$ of selenium is $55 \mu \mathrm{g}$ a day for men and women ages 19 years and older [29]. Additional studies are needed to determine the ideal daily dose of selenium to achieve maximal skin benefit. 
Zinc

Zinc is an essential mineral found naturally in whole grains, red meat, seafood, and fortified in products such as cereal [10]. Zinc is an important cofactor for cellular activity and defense. It protects against lipid peroxidation, UV-induced cytotoxicity, and oxidative stress induced by ROS made and distributed within the cytosol by macrophages [27, 28].

The majority of the skin's zinc stores are found in the epidermis, where it is a necessary element for epidermal proliferation and keratinocyte differentiation [30]. Zinc plays a major role in wound healing and keratinocyte cell survival [30]. It is also anti-inflammatory by hindering intercellular adhesion molecule 1, a pro-inflammatory marker of keratinocytes, and decreasing the production of nitric oxide [30].

In 2001, it was estimated that $10 \%$ of the US population consumes less than $50 \%$ of the recommend daily allowance of zinc [31]. The bioavailability of zinc is mainly dependent on zinc's absorption and reabsorption properties found within the human intestines [10]. Varying concentrations of elements such as iron, copper, calcium, phosphate, and folate influence the bioavailability of zinc in the body [10]. Zinc is found in highest dietary concentrations in foods such as non-milled whole grains, red meats, and seafood [10]. The Food and Nutrition Board of the Institute of Medicine's RDA of zinc is $11 \mathrm{mg}$ a day for men and $8 \mathrm{mg}$ a day for women ages 19 years and older [10]. Additional studies are needed to determine the ideal daily dose of zinc to achieve maximal skin benefit.

\section{POLYPHENOLS}

Polyphenols are secondary metabolites of plants and are found predominately in fruits, vegetables, cereals, and beverages [32]. For years, polyphenols have been of interest for their antimutagenic, anticarcinogenic, anti-inflammatory, and antioxidant properties [28, 33]. Extensive research has shown that through these properties different polyphenols can be protective against numerous health concerns including cancer, hypertension, asthma, diabetes, cardiovascular disease, and infection [32]. Over eight thousand different polyphenol compounds have been identified, but here only two will be discussed: curcumin and epigallocatechin gallate (EGCG) [32].

\section{Curcumin}

Curcumin is a polyphenol derived from the turmeric spice. It has a yellow pigment, which is responsible for the characteristic yellow color of curry [34]. Curcumin serves many biologically active roles, as does EGCG, including the alike anticarcinogenic, anti-inflammatory, and antioxidant roles [33].

Similarity to EGCG, curcumin has been suggested as a potential treatment for cancer because of its ability to hinder the production of cancer cells and encourage apoptosis [35]. It has been shown to promote cell death by influencing the expression of p53 and decreasing the production of nuclear factor kappa B [33].

Curcumin's anti-inflammatory properties are exhibited through its ability to suppress proinflammatory cytokines including chemokines, cyclooxygenase-2, prostaglandin $\mathrm{E}_{2}$, MMPs, interleukins (IL) such as IL-6 and IL-12, and tumor necrosis factor- $\alpha$ [34, 35]. In addition, curcumin serves as an antioxidant by suppressing ROS production, scavenging free oxygen radicals, and inhibiting lipid peroxidation $[34,35]$.

In 2017, Shailaja et al. studied curcumin's anti-inflammatory properties in albino rats as a potential anti-aging nutraceutical. The study compared three dosages of oral daily curcumin supplementation against two different standard rat feed and water diets. They report a statistically significant decrease in the C-reactive protein levels in the curcumin-supplemented group compared with the two control groups [36].

The Food and Nutrition Board of the Institute of Medicine's RDA of curcumin has not been established; however, the United States Food and Drug Administration (FDA) has labeled curcumin safe for ingestion and pharmacologic use [35]. In 2016, Pal et al. [33] reported two studies of safe oral 
supplementation of curcumin between 2-8 $\mathrm{g}$ per $\mathrm{kg}$ daily. Further studies are needed to determine the optimal daily allowance while accessing for supplementation health risks.

\section{Epigallocatechin Gallate (Egcg)}

Tea polyphenols inhibit lipid peroxidation, limit the amount of UV radiation-induced DNA damage, and reduce the amount ROS and free radicals produced in the skin [28, 34]. EGCG is the most potent tea polyphenol and is commonly found in green tea $[17,28]$. EGCG has anti-inflammatory effects via the suppression of pro-inflammatory inducers such as cyclooxygenase-2, MMPs, tumor necrosis factor- $\alpha$, and IL6,8 , and 12 [33]. Studies have also shown that EGCG can diminish melanoma cell growth in humans by supporting cell cycle arrest and apoptosis [33].

Health benefits of EGCG have been shown with both topical application and ingestion, although some benefits are only seen with one delivery method and not the other. In mice, studies have shown diminished radiation-induced effects with topical application. These effects include deceased edema and erythema, preservation of skin antioxidant stores, and reduction of UV-induced skin tumors [3, 17].

Green tea has been reported to consist of the most polyphenol antioxidants, and the highest concentration of EGCG is found within green tea leaves [17]. It is commercially available as a white powder for oral consumption [17]. The Food and Nutrition Board of the Institute of Medicine's RDA of EGCG has not been established. In 2017, Yates et al. completed an extensive literature search evaluating the toxicity level of EGCG in daily human consumption. The results were inconclusive and need future investigation; however, publications by France and Italy report a proposed upper limit of approximately $300 \mathrm{mg}$ per day of EGCG [37]. Pal et al. report a phase I clinical study with 200-1200 mg of daily consumption being well tolerated [33]. Further studies are needed to determine the optimal daily allowance while accessing for supplementation health risks.

\section{VITAMINS}

\section{Vitamin C}

Vitamin C is a water-soluble compound. Bodily concentrations are maintained through consumption of vitamin $\mathrm{C}$, as humans cannot synthesize ascorbic acid de novo. Oxidation of vitamin $\mathrm{C}$ produces dehydroxy ascorbic acid, which is shifted into our cells via glucose transporters and then reduced back to ascorbic acid for cellular use [38]. Studies have shown that oral vitamin $\mathrm{C}$ supplementation leads to an increase in its plasma and skin content [39].

Vitamin $\mathrm{C}$ is a powerful antioxidant and free radical scavenger that protects our tissues, cell membranes, and DNA from oxidative damage. It also serves as an essential cofactor and electron donor during collagen hydroxylation, encouraging the maturation of intracellular and extracellular collagen [26]. Vitamin $C$ has been shown to reduce UVB-induced oxidative damage and UV radiation-induced skin neoplasms in mice and protect human keratinocytes from UVA-induced lipid peroxidation [39, 40]. Vitamin $C$ also decreases the malondialdehyde content in the skin, which is a marker of oxidative stress $[39,40]$.

Food sources containing the highest concentrations of vitamin $\mathrm{C}$ are raw red and green peppers, oranges, grapefruits, kiwifruit, broccoli, strawberries, and Brussels sprouts [41]. The Food and Nutrition Board of the Institute of Medicine's RDA of vitamin C is $90 \mathrm{mg}$ a day for men and $75 \mathrm{mg}$ a day for women ages 19 years and older [29]. National surveys indicate that most adults and children in the US consume their RDA of vitamin C [41]. Additional studies are needed to determine the ideal daily dose of vitamin $\mathrm{C}$ to achieve maximal skin benefit.

\section{Vitamin E}

Vitamin E is a group of fat-soluble compounds. The most abundant and biologically active form of vitamin E, alpha-tocopherol $(\alpha \mathrm{T})$, is the leading form used in human metabolism [3, 42]. $\alpha \mathrm{T}$ protects the skin from UVB damage by halting the formation of ROS, scavenging free 
radicals, stabilizing the surface and membranes of cells, reducing the number of apoptotic cells, and minimizing the activation of nuclear factor kappa B $[26,43]$. $\alpha \mathrm{T}$ is also believed to be photoprotective as multiple studies have shown that $\alpha \mathrm{T}$ in combination with vitamin $\mathrm{C}$ supplementation increases the MED [3].

UV light reduces the skin's concentration of $\alpha \mathrm{T}$, promoting skin aging [3]. Luckily, the skin's concentration of $\alpha \mathrm{T}$ can be increased with oral or topical delivery [3]. Naturally occurring oral sources of vitamin $\mathrm{E}$ are found in highest concentrations in plant seeds such as sunflower seeds, peanuts, almonds, walnuts, pecans, pistachios, and sesame seeds and in lesser amounts in fruits and vegetables [44, 45]. The Food and Nutrition Board of the Institute of Medicine's RDA of vitamin $\mathrm{E}$ is $15 \mathrm{mg}$ a day for men and women ages 19 years and older [29]. National surveys have found that most Americans consume less than their RDA of vitamin E [46]. However, these intake estimates might be low because they did not account for the fats added while cooking [46]. No adverse effects have been reported from consuming vitamin $\mathrm{E}$ in food; however, hemorrhage and altered blood coagulation were reported in animals who consumed supplements containing high doses of $\alpha \mathrm{T}$ [46]. Additional studies are needed to determine the ideal daily allowance of vitamin $\mathrm{E}$ to achieve maximal skin benefit.

\section{POTENTIAL FUTURE NUTRACEUTICALS}

\section{Aloe Sterol}

Collagen and elastin are the two main fibers in the dermis and together makeup and maintain the majority of the skin's structure [47]. Degradation of these fibers, which is seen in chronologically aged skin, leads to a decrease in cutaneous elasticity and an increase in cutaneous fragility [47]. Oral Aloe sterols have been shown to encourage the formation of type I and type III collagen in human dermal fibroblasts, leading to increased collagen production and improved skin elasticity [48]. They have also been found to decrease the expression of MMP-2 and MMP-9, protecting collagen and the ECM from degradation, in UVB-irradiated hairless mice [47]. In addition, studies have showed that oral Aloe sterol may encourage the production of hyaluronic acid in human dermal fibroblasts [49]. Further studies are needed to determine the role of oral Aloe sterols and optimal daily allowance while accessing for supplementation health risks.

\section{Serenoa Repens}

Serenoa repens, also known as saw palmetto, is a low-growing palm tree native to the Southeast US and West Indies [50]. The berries of the palm tree contain fatty acids and phytosterols that have antiandrogenic activity through inhibition of 5-alpha reductase [51]. It is well known as an herbal treatment of benign prostatic hyperplasia and lower urinary symptoms such as weak urine flow, hesitancy, incomplete emptying, frequency, urgency, and nocturia [50]. Over the past few years, Serenoa repens has become of interest for potentially treating androgenetic alopecia (AGA).

One study found that $320 \mathrm{mg}$ a day of Serenoa repens improved AGA in 38\% of patients and stabilized AGA in $52 \%$ of the patients, but on the vertex scalp [51]. It is important to mention that this improvement was not as significant as that in patients treated with finasteride. In the same study, $68 \%$ of patients who took $1 \mathrm{mg}$ a day of finasteride had improvement of their AGA in both the vertex and anterior scalp regions [51].

Serenoa repens is generally tolerated well and has not been associated with any serious adverse events [50]. The most common adverse events reported are abdominal pain, diarrhea, nausea, vomiting, headache, decreased libido, and rhinitis [50]. Serenoa repens, like other 5-alpha reductase inhibitors, reduces prostate-specific antigen levels by $50 \%$ after $6-12$ months of treatment [51]. More studies are needed to assess the role of Serenoa repens in the treatment of AGA.

\section{CONCLUSIONS}

The aim of this review was to aid dermatologists in better understanding the mechanism of 
action, efficacy, and potential dermatologic benefits of popular nutraceuticals. For the majority of nutraceuticals mentioned here, patients who consume a healthy balanced diet are most likely obtaining adequate amounts of these nutrients to receive the aforementioned skin benefits. However, if diets are lacking key nutritional components, supplementation may be of benefit to those patients. It is important for providers to discuss the benefits and consequences of nutraceuticals with patients and to mention the importance of a recommended daily allowance as most things consumed in excess have the potential to cause adverse effects. With advances in technology and the expansion of the online consumer market, it is vital that providers offer an authenticated, medically certified, and safe avenue to purchasing the recommended nutraceuticals.

\begin{tabular}{|c|c|c|c|c|c|}
\hline $\begin{array}{l}\text { Major } \\
\text { subtype of } \\
\text { nutraceutical }\end{array}$ & Nutraceutical & MOA & RDA & Oral source & Skin function \\
\hline Amino acids & $N$-Acetylcysteine & $\begin{array}{l}\text { Increase in red blood cell glycine, } \\
\text { cysteine, glutathione } \\
\text { concentrations; decline in } \\
\text { oxidative stress and plasma } \\
\text { markers for oxidant damage }\end{array}$ & $\begin{array}{l}\text { Not yet established by FNBIM. } \\
\text { Further studies needed }\end{array}$ & $\begin{array}{l}\text { Cysteine and glycine } \\
\text { supplementation }\end{array}$ & $\begin{array}{l}\text { Protects against oxidative stress } \\
\text { (i.e., DNA damage and } \\
\text { aging) }\end{array}$ \\
\hline Carotenoids & $\beta$-Carotene & $\begin{array}{l}\text { Inhibits free radicals and singlet } \\
\text { oxygen-induced lipid } \\
\text { peroxidation; decreases MMP-9 } \\
\text { activity }\end{array}$ & $\begin{array}{l}\text { Supplemental all-trans- } \beta \text {-carotene: } \\
1800 \mu \mathrm{g} / \text { day for men; } \\
1400 \mu \mathrm{g} / \text { day for women. } \\
\text { Dietary all-trans- } \beta \text {-carotene is } \\
10,800 \mu \mathrm{g} / \text { day for men; } \\
8400 \mu \mathrm{g} / \text { day for women }\end{array}$ & $\begin{array}{l}\text { Green leafy } \\
\text { vegetables, orange } \\
\text { root vegetables, } \\
\text { yellow or orange } \\
\text { fruits }\end{array}$ & $\begin{array}{l}\text { Scavenges ROS to protect } \\
\text { against oxidative stress and } \\
\text { decrease UV exposure; } \\
\text { protects against ECM } \\
\text { degradation }\end{array}$ \\
\hline Carotenoids & $\begin{array}{l}\text { Lutein and } \\
\text { zeaxanthin }\end{array}$ & $\begin{array}{l}\text { Blocks damaging blue wavelengths } \\
\text { and prevents free radical damage }\end{array}$ & $\begin{array}{l}\text { Not yet established by FNBIM. } \\
\text { Proposed quantity: lutein } \\
6-10 \mathrm{mg} / \text { day and zeaxanthin } \\
2 \mathrm{mg} / \text { day }\end{array}$ & $\begin{array}{l}\text { Green leafy } \\
\text { vegetables, eggs }\end{array}$ & $\begin{array}{l}\text { Antioxidant and decrease UV } \\
\text { exposure }\end{array}$ \\
\hline Carotenoids & Lycopene & $\begin{array}{l}\text { Singlet oxygen quencher; decreases } \\
\text { MMP-1 activity; induces cell-cycle } \\
\text { arrest and induces apoptosis }\end{array}$ & $\begin{array}{l}\text { Not yet established by FNBIM. } \\
\text { Further studies needed }\end{array}$ & $\begin{array}{l}\text { Tomato paste, } \\
\text { tomatoes, pink } \\
\text { grapefruit, } \\
\text { watermelon }\end{array}$ & $\begin{array}{l}\text { Lowers UV-induced erythema; } \\
\text { decreases collagen } \\
\text { breakdown; inhibits } \\
\text { proliferation of certain } \\
\text { cancer cells; decreases skin } \\
\text { roughness }\end{array}$ \\
\hline Fatty acids & $\begin{array}{l}\alpha \text {-Linolenic acid } \\
\text { (ALA), } \\
\text { eicosapentaenoic } \\
\text { acid, and } \\
\text { docosahexaenoic } \\
\text { acid }\end{array}$ & $\begin{array}{l}\text { Inhibits formation of pro- } \\
\text { inflammatory cytokines (i.e., } \\
\text { prostaglandins, leukotrienes); } \\
\text { decreases prostaglandin- } \mathrm{E}_{2} \\
\text { production }\end{array}$ & $\begin{array}{l}\text { Not yet established by FNBIM. } \\
\text { Adequate intake for linoleic } \\
\text { acid: } 17 \mathrm{~g} / \text { day for men and } \\
12 \mathrm{~g} / \text { day for women ages } \\
19-50 ; 14 \mathrm{~g} / \text { day men and } \\
11 \mathrm{~g} / \text { day women ages } 51+\text { AI } \\
\text { for ALA } 1.6 \mathrm{~g} / \text { day men and } \\
1.1 \mathrm{~g} / \text { day women, ages } 19+\end{array}$ & $\begin{array}{l}\text { Flaxseed oil, canola } \\
\text { oil, hemp seed oil, } \\
\text { cold-water fish } \\
\text { (salmon, trout), } \\
\text { nuts, seeds }\end{array}$ & $\begin{array}{l}\text { Anti-inflammatory; reduces } \\
\text { UVR-induced inflammation; } \\
\text { increases MED }\end{array}$ \\
\hline Minerals & Selenium & $\begin{array}{l}\text { Aids glutathione peroxidases and } \\
\text { thioredoxin reductases, removing } \\
\text { damaging lipid hydroperoxides, } \\
\text { hydrogen peroxide, peroxynitrites }\end{array}$ & $55 \mu \mathrm{g} /$ day men and women $19+$ & Meat and seafood & $\begin{array}{l}\text { Supports DNA synthesis and } \\
\text { repair, cell apoptosis and } \\
\text { guards against oxidative } \\
\text { damage, leading to cell } \\
\text { membrane stabilization and } \\
\text { protects against DNA } \\
\text { damage }\end{array}$ \\
\hline
\end{tabular}


continued

\begin{tabular}{|c|c|c|c|c|c|}
\hline $\begin{array}{l}\text { Major } \\
\text { subtype of } \\
\text { nutraceutical }\end{array}$ & Nutraceutical & MOA & RDA & Oral source & Skin function \\
\hline Minerals & Zinc & $\begin{array}{l}\text { Protects against lipid peroxidation, } \\
\text { UVR-induced cytotoxicity, and } \\
\text { oxidative stress. Necessary for } \\
\text { epidermal proliferation and } \\
\text { keratinocyte differentiation. } \\
\text { Hinders intracellular adhesion } \\
\text { molecule } 1 \text {; decreases nitric oxide } \\
\text { production }\end{array}$ & $\begin{array}{l}11 \mathrm{mg} / \text { day men; } 8 \mathrm{mg} / \text { day } \\
\text { women } 19+\end{array}$ & $\begin{array}{l}\text { Non-milled whole } \\
\text { grains, red meat, } \\
\text { seafood, fortified } \\
\text { products (i.e., } \\
\text { cereal) }\end{array}$ & $\begin{array}{l}\text { Cofactor for cellular activity and } \\
\text { defense; skin cell } \\
\text { proliferation; wound healing; } \\
\text { anti-inflammatory properties }\end{array}$ \\
\hline Polyphenols & Curcumin & $\begin{array}{l}\text { Hinders production of cancer cells, } \\
\text { encourages apoptosis, promotes } \\
\text { cell death by influencing } \mathrm{p} 53 \\
\text { expression and decreases NF- } \mathrm{KB} \\
\text { production. Suppresses pro- } \\
\text { inflammatory cytokines. } \\
\text { Suppresses ROS production by } \\
\text { scavenging free oxygen radicals; } \\
\text { inhibits lipid peroxidation. } \\
\text { Decreases C-reactive protein }\end{array}$ & $\begin{array}{l}\text { Not yet established by FNBIM. } \\
2-8 \mathrm{~g} / \mathrm{kg} / \text { day has been } \\
\text { suggested }\end{array}$ & Turmeric spice, curry & $\begin{array}{l}\text { Anticarcinogenic, anti- } \\
\text { inflammatory, and } \\
\text { antioxidant properties }\end{array}$ \\
\hline Polyphenols & $\begin{array}{l}\text { Epigallocatechin } \\
\text { gallate (EGCG) }\end{array}$ & $\begin{array}{l}\text { Inhibits lipid peroxidation, limits } \\
\text { UVR-induced DNA damage, } \\
\text { reduces ROS and free radical } \\
\text { production. Suppresses pro- } \\
\text { inflammatory inducers (i.e., } \\
\text { cyclooxygenase-2, MMPs). } \\
\text { Supports cell cycle arrest and } \\
\text { apoptosis }\end{array}$ & $\begin{array}{l}\text { Not yet established by FNBIM. } \\
\text { Proposed upper limit of } \\
\text { approximately } 300 \mathrm{mg} / \text { day }\end{array}$ & $\begin{array}{l}\text { Green tea leaves, } \\
\text { green tea, } \\
\text { commercially } \\
\text { available in white } \\
\text { powder form }\end{array}$ & $\begin{array}{l}\text { Antioxidant, anti-inflammatory, } \\
\text { and anticarcinogenic } \\
\text { properties; reduces UVR- } \\
\text { induced erythema/edema }\end{array}$ \\
\hline $\begin{array}{c}\text { Vitamins; } \\
\text { water- } \\
\text { soluble }\end{array}$ & Vitamin C & $\begin{array}{l}\text { Free radical scavenger; essential } \\
\text { cofactor and electron donor } \\
\text { during collagen hydroxylation. } \\
\text { Reduces UVB-induced oxidative } \\
\text { damage. Protects against UVA- } \\
\text { induced lipid peroxidation. } \\
\text { Decreases malondialdehyde }\end{array}$ & $\begin{array}{l}90 \mathrm{mg} / \text { day men; } 75 \mathrm{mg} / \text { day } \\
\text { women } 19+\end{array}$ & $\begin{array}{l}\text { Raw red and green } \\
\text { peppers, oranges, } \\
\text { grapefruits, } \\
\text { kiwifruit, } \\
\text { broccoli, } \\
\text { strawberries, } \\
\text { Brussels sprouts }\end{array}$ & $\begin{array}{l}\text { Powerful antioxidant; } \\
\text { encourages intracellular and } \\
\text { extracellular collagen } \\
\text { production }\end{array}$ \\
\hline $\begin{array}{l}\text { Vitamins; fat- } \\
\text { soluble }\end{array}$ & $\begin{array}{l}\text { Vitamin E; alpha- } \\
\text { tocopherol }(\alpha \mathrm{T})\end{array}$ & $\begin{array}{l}\text { Halts formation of reactive oxygen } \\
\text { species, scavenges free radicals, } \\
\text { stabilizes cell membranes, reduces } \\
\text { apoptotic cells, minimizes } \\
\text { activation of nuclear factor kappa } \\
\text { B (NF-kB) }\end{array}$ & $15 \mathrm{mg} /$ day men and women $19+$ & $\begin{array}{l}\text { Sunflower seeds, } \\
\text { peanuts, almonds, } \\
\text { walnuts, pecans, } \\
\text { pistachios, sesame } \\
\text { seeds, fruits, and } \\
\text { vegetables }\end{array}$ & $\begin{array}{l}\text { Protects against UVB damage; } \\
\text { photo-protective properties; } \\
\text { increases MED }\end{array}$ \\
\hline
\end{tabular}

FNBIM The Food and Nutrition Board of the Institute of Medicine, MED minimal erythema dose, MMP matrix metalloproteinase, UVR ultraviolet radiation

Potential future nutraceuticals

\begin{tabular}{|c|c|c|c|c|}
\hline Nutraceutical & MOA & RDA & Oral source & Skin function \\
\hline Aloe sterol & $\begin{array}{l}\text { Encourage formation of type I } \\
\text { and III collagen in dermal } \\
\text { fibroblasts; decrease } \\
\text { expression of MMP-2 and } \\
\text { MMP-9; potentially } \\
\text { increases hyaluronic acid in } \\
\text { dermal fibroblasts }\end{array}$ & $\begin{array}{l}\text { Not yet established by } \\
\text { FNBIM. Further } \\
\text { studies needed }\end{array}$ & $\begin{array}{l}\text { Not yet } \\
\text { commercially } \\
\text { available }\end{array}$ & $\begin{array}{l}\text { Increase collagen } \\
\text { production, improve } \\
\text { skin elasticity; protects } \\
\text { against collagen and } \\
\text { ECM degradation; } \\
\text { potentially increases } \\
\text { hyaluronic acid in } \\
\text { dermis }\end{array}$ \\
\hline
\end{tabular}


continued

\begin{tabular}{|c|c|c|c|c|}
\hline Nutraceutical & MOA & RDA & Oral source & Skin function \\
\hline $\begin{array}{l}\text { Serenoa repens } \\
\text { (saw } \\
\text { palmetto) }\end{array}$ & Inhibits 5-alpha reductase & $\begin{array}{l}\text { Not yet established by } \\
\text { FNBIM. Proposed } \\
\text { studied amounts range } \\
\text { from } \\
320 \mathrm{mg} / \text { day-1 g/day }\end{array}$ & Supplementation & $\begin{array}{l}\text { Antiandrogenic activity, } \\
\text { potential treatment of } \\
\text { androgenetic alopecia }\end{array}$ \\
\hline
\end{tabular}

\section{ACKNOWLEDGEMENTS}

Funding. No funding or sponsorship was received for this review or publication of this article.

Authorship. All named authors meet the International Committee of Medical Journal Editors (ICMJE) criteria for authorship for this manuscript, take responsibility for the integrity of the work as a whole, and have given final approval to the version to be published.

Disclosures. Dr. Mary Lupo discloses that she is a speaker for Allergan, Cutera, Galderma, La Roche-Posay, Merz, Theraplex, and Lumity Life, Inc. Dr. Mary Lupo also sits on the Advisory Board for Allergan, Galderma, TopMD, and Eastern College of Health Vocations, LLC. She is a Clinical Investigator for Allergan, Revance Therapeutics, and Foamix Pharmaceuticals, Inc. Dr. Mary Lupo is an Alphaeon and TopMD stockholder and has an ownership interest in Cosmetic Bootcamp. She is also a consultant for Solta/Valeant and Theraplex. Dr. Skylar Souyoul is a Sub-Investigator for Revance Therapeutics and Foamix Pharmaceuticals, Inc. Dr. Katharine Saussy has nothing to disclose.

Compliance with Ethics Guidelines. This article is based on previously conducted studies, and does not involve any new studies of human or animal subjects performed by any of the authors.

Data Availability. This manuscript has no associated data to be deposited.
Open Access. This article is distributed under the terms of the Creative Commons Attribution-NonCommercial 4.0 International License (http://creativecommons.org/licenses/ by-nc/4.0/), which permits any noncommercial use, distribution, and reproduction in any medium, provided you give appropriate credit to the original author(s) and the source, provide a link to the Creative Commons license, and indicate if changes were made.

\section{REFERENCES}

1. Dumoulin M, Gaudout D, Lemaire B. Clinical effects of an oral supplement rich in antioxidants on skin radiance in women. Clin Cosmet Investig Dermatol. 2016;9:315-24.

2. Bolognia JL, Jorizzo JL, Schaffer JV. Evaluation of beauty and the aging face. Dermatology. London: Elsevier; 2012. 2473-8. Print.

3. Evans JA, Johnson EJ. The role of phytonutrients in skin health. Nutrients. 2010;2:903-28.

4. Chauhan B, Kumar G, Kalam N, Ansari SH. Current concepts and prospects of herbal nutraceutical: a review. J Adv Pharm Technol Res. 2013;4:4-8.

5. Cassidy PB, Liu T, Florell SR, Honeggar M, Leachman SA, Boucher KM, Grossman D. A phase II randomized placebo-controlled trial of oral $\mathrm{N}$ acetylcysteine for protection of melanocytic nevi against UV-induced oxidative stress in vivo. Cancer Prev Res (Phila). 2017;10:36-44.

6. Kang S, Chung JH, Lee JH, Fisher GJ, Wan YS, Duell EA, Voorhees JJ. Topical $\mathrm{N}$-acetyl cysteine and genistein prevent ultraviolet-light-induced signaling that lead to photoaging in human skin in vivo. J Invest Dermatol. 2003;120:835-41. 
7. Sekhar RV, Patel SG, Guthikonda AP, Reid M, Balasubramanyam A, Taffet GE, Jahoor F. Deficient synthesis of glutathione underlies oxidative stress in aging and can be corrected by dietary cysteine and glycine supplementation. Am J Clin Nutr. 2011;94:847-53.

8. Fiedor J, Burda K. Potential role of carotenoids as antioxidants in human health and disease. Nutrients. 2014;6:466-88.

9. Grether-Beck S, Marini A, Jaenicke T, Stahl W, Krutmann J. Molecular evidence that oral supplementation with lycopene or lutein protects human skin against ultraviolet radiation: results from a double-blinded, placebo-controlled, crossover study. Br J Dermatol. 2016;176:1231-40.

10. Institute of Medicine: Food and Nutrition Board. Dietary reference intakes for vitamin A, vitamin K, arsenic, boron, chromium, copper, iodine, iron, manganese, molybdenum, nickel, silicon, vanadium, and zinc. Washington, DC: National Academy Press; 2001. https://www.nap.edu/read/10026/ chapter/9\#242.

11. Schwartz S, Frank E, Gierhart D, et al. Zeaxanthinbased dietary supplement and topical serum improve hydration and reduce wrinkle count in female subjects. J Cosmet Dermatol. 2016;15:e13-20.

12. Juturu V, Bowman JP, Deshpande J. Overall skin tone and skin-lightening-improving effects with oral supplementation of lutein and zeaxanthin isomers: a double-blind, placebo-controlled clinical trial. Clin Cosmet Investig Dermatol. 2016;9:325-32.

13. Roberts RL, Green J, Lewis B. Lutein and zeaxanthin in eye and skin health. Clin Dermatol. 2009;27:195-201.

14. Jia YP, Sun L, Yu HS, Liang LP, Ding H, Song XB, Zhang LJ. The pharmacological effects of lutein and zeaxanthin on visual disorders and cognition diseases. Molecules. 2017;22:1-22.

15. American Optometric Association. Lutein \& Zeaxanthin [Internet]. Missouri: American Optometric Association; c2017 [cited 2017 May 12]. https:// www.aoa.org/patients-and-public/caring-for-yourvision/diet-and-nutrition/lutein?sso=y. Accessed 17 May 2017.

16. Stahl W, Sies H. $\beta$-Carotene and other carotenoids in protection from sunlight. Am J Clin Nutr. 2012;96:1179S-84S.

17. Draelos ZD. Nutrition and enhancing youthful-appearing skin. Clin Dermatol. 2010;28:400-8.
18. Wang P, Sun M, Ren J, Djuric Z, Fisher GJ, Wang X, Li Y. Gas chromatography-mass spectrometry analysis of effects of dietary fish oil on total fatty acid composition in mouse skin. Sci Rep. 2017;7:42641.

19. Kendall AC, Kiezel-Tsugunova M, Brownbridge LC, Harwood JL, Nicolaou A. Lipid functions in skin: differential effects of n-3 polyunsaturated fatty acids on cutaneous ceramides, in a human skin organ culture model. Biochim Biophys Acta. 2017;1859:1679-89.

20. McCusker MM, Grant-Kels JM. Healing fats of the skin: the structural and immunologic roles of the omega- 6 and omega- 3 fatty acids. Clin Dermatol. 2010;28:440-51.

21. Yoshida S, Yasutomo K, Watanabe T. Treatment with DHA/EPA ameliorates atopic dermatitis-like skin disease by blocking LTB4 production. J Med Invest. 2016;63:187-91.

22. Institute of Medicine: Food and Nutrition Board. Dietary reference intakes for energy, carbohydrate, fiber, fat, fatty acids, cholesterol, protein, and amino acids. Washington, DC: National Academy Press; 2005.

23. Yeowell HN, Marshall MK, Walker LC, Ha V, Pinnell SR. Regulation of lysyl oxidase mRNA in dermal fibroblasts from normal donors and patients with inherited connective tissue disorders. Arch Biochem Biophys. 1994;308:299-305.

24. Kanteev M, Goldfeder M, Fishman A. Structurefunction correlations in tyrosinases. Protein Sci. 2015;24:1360-9.

25. Driscoll MS, Kwon EK, Skupsky H, Kwon SY, GrantKels JM. Nutrition and the deleterious side effects of nutritional supplements. Clin Dermatol. 2010;28:371-9.

26. Wu X, Cheng J, Wang X. Dietary antioxidants: potential anticancer agents. Nutr Cancer. 2017;69:521-33.

27. Wintergerst ES, Maggini S, Hornig DH. Contribution of selected vitamins and trace elements to immune function. Ann Nutr Metab. 2007;51:301-23.

28. Pinnell SR. Cutaneous photodamage, oxidative stress, and topical antioxidant protection. J Am Acad Dermatol. 2003;48:1-19.

29. Institute of Medicine: Food and Nutrition Board. Dietary reference intakes: vitamin $\mathrm{C}$, vitamin $\mathrm{E}$, selenium, and carotenoids. Washington, DC: National Academy Press; 2000. https://www.nap. edu/read/9810/chapter/1\#xix. 
30. Ogawa Y, Kawamura T, Shimada S. Zinc and skin biology. Arch Biochem Biophys. 2016;611:113-9.

31. Ho E, Courtemanche C, Ames BN. Zinc deficiency induces oxidative DNA damage and increases p53 expression in human lung fibroblasts. J Nutr. 2003;133:2543-8.

32. Pandey KB, Rizvi SI. Plant polyphenols as dietary antioxidants in human health and disease. Oxidative Med Cell Longev. 2009;2:270-8.

33. Pal HC, Hunt KM, Diamond A, Elmets CA, Afaq F. Phytochemicals for the management of melanoma. Mini Rev Med Chem. 2016;16:953-79.

34. Krausz A, Gunn H, Friedman A. The basic science of natural ingredients. J Drugs Dermatol. 2014;13:937-43.

35. Perrone D, Ardito F, Giannatempo G, Dioguardi M, Troiano G, Lo Russo L, DE Lillo A, Laino L, Lo Muzio L. Biological and therapeutic activities, and anticancer properties of curcumin. Exp Ther Med. 2015;10:1615-23.

36. Shailaja M, Damodara Gowda KM, Vishakh K, Suchetha Kumari N. Anti-aging role of curcumin by modulating the inflammatory markers in albino wistar rats. J Natl Med Assoc. 2017;109:9-13.

37. Yates AA, Erdman JW Jr, Shao A, Dolan LC, Griffiths JC. Bioactive nutrients-time for tolerable upper intake levels to address safety. Regul Toxicol Pharmacol. 2017;84:94-101.

38. Subramani T, Yeap SK, Ho WY, Ho CL, Omar AR, Aziz SA, Rahman NM, Alitheen NB. Vitamin C suppresses cell death in MCF-7 human breast cancer cells induced by tamoxifen. J Cell Mol Med. 2014;18:305-13.

39. McArdle F, Rhodes LE, Parslew R, Jack CIA, Friedmann PS, Jackson MJ. UVR-induced oxidative stress in human skin in vivo: effects of oral vitamin $\mathrm{C}$ supplementation. Free Radic Biol Med. 2002;33:1355-62.

40. Tebbe B, Wu S, Geilen CC, Eberle J, Kodelja V, Orfanos CE. L-ascorbic acid inhibits UVA-inducted lipid peroxidation and secretion of IL- $1 \alpha$ and IL- 6 in cultured human keratinocytes in vitro. J Invest Dermatol. 1997;108:302-6.
41. Vitamin C Fact Sheet for Health Professionals (2016, February 11). https://ods.od.nih.gov/ factsheets/VitaminC-HealthProfessional/. Accessed 17 May 2017.

42. Jiang Q. Natural forms of vitamin E: metabolism, antioxidant and anti-inflammatory activities and the role in disease prevention and therapy. Free Radic Biol Med. 2014;72:76-90.

43. Maalouf S, El-Sabban M, Darwiche N, Gali-Muhtasib $\mathrm{H}$. Protective effect of vitamin E on ultraviolet B light-induced damage in keratinocytes. Mol Carcinog. 2002;34:121-30.

44. McLaughlin PJ, Weihrauch JL. Vitamin E content of foods. J Acad Nutr Diet. 1979;75:647-65.

45. Dreher ML. Pistachio nuts: composition and potential health benefits. Nutr Rev. 2012;70:234-40.

46. Vitamin E Fact Sheet for Health Professionals (2016, November 3). https://ods.od.nih.gov/factsheets/ VitaminE-HealthProfessional/. Accessed 17 May 2017.

47. Tanaka M, Yamamoto Y, Misawa E, Nabeshima K, Saito M, Yamauchi K, Abe F, Furukawa F. Effects of aloe sterol supplementation on skin elasticity, hydration, and collagen score: a 12-week doubleblind, randomized, controlled trial. Skin Pharmacol Physiol. 2016;29:309-17.

48. Tanaka M, Misawa E, Yamauchi K, Abe F, Ishizaki C. Effects of plant sterols derived from Aloe vera gel on human dermal fibroblasts in vitro and on skin condition in Japanese women. Clin Cosmet Investig Dermatol. 2015;8:95-104.

49. Misawa E, Tanaka M, Saito M, Nabeshima K, Yao R, Yamauchi K, Furukawa F. Protective effects of Aloe sterols against UVB-induced photoaging in hairless mice. Photodermatol Photoimmunol Photomed. 2017;33:101-11.

50. Agbabiaka TB, Pittler MH, Wider B, Ernst E. Serenoa repens (saw palmetto): a systematic review of adverse events. Drug Saf. 2009;32:637-47.

51. Rossi A, Mari E, Scarno M, Garelli V, Maxia C, Scali E, Iorio A, Carlesimo M. Comparative effectiveness of finasteride $v s$ serenoa repens in male androgenetic alopecia: a two-year study. Int J Immunopathol Pharmacol. 2012;25:1167-73. 